\title{
ANALISA FAKTOR-FAKTOR PENYEBAB GANGGUAN JIWA MENGGUNAKAN PENDEKATAN MODEL ADAPTASI STRES STUART
}

\author{
Fajar Rinawati, Moh Alimansur \\ Dosen Akedemi Keperawatan Dharma Husada Kediri, Jl. Penanggungan No. 41 A Kediri \\ Email: ukhti_fajr@yahoo.com, ali.mansur75@yahoo.co.id
}

\begin{abstract}
Mental disorder can occus in all people, either children, adults or elderly. Mental disorder also can occurs anywhere, either people that living in cities or villages. The caused of mental disorder derived from biological, psychological and social aspects. The purpose of this study was to determine the factors that caused mental disorder. The methodology of this study was quantitative descriptive using purposive sampling for 9 weeks. The sample of this study was 46 respondents. The results showed that the most predispocing factor was the client ever experienced previous mental disorder before, personality type and unemployment client, and the most precipitation factor was withdrawal, an unpleasant experience and conflicts with family and friends. Based on the results of this study expected that the nursing intervention for client with mental disorder not only treating the signs and symtoms but also preventing mental disorder to overcome/reduce the factors.
\end{abstract}

Keywords: mental disorder, etyology, and analysis of factor

\section{PENDAHULUAN}

Kesehatan jiwa merupakan bagian yang tidak terpisahkan dari kesehatan secara umum serta merupakan dasar bagi pertumbuhan dan perkembangan manusia. Kesehatan jiwa membuat perkembangan fisik, intelektual dan emosional seseorang berkembang optimal selaras dengan perkembangan orang lain (UU No 36, 2009).

WHO (2009) memperkirakan 450 juta orang di seluruh dunia mengalami gangguan mental, sekitar $10 \%$ orang dewasa mengalami gangguan jiwa dan $25 \%$ penduduk diperkirakan akan mengalami gangguan jiwa pada usia tertentu dalan rentang hidupnya yan biasanya terjadi pada dewasa muda antara usia 18-21 tahun. Menurut National institute of mental health, gangguan jiwa mencapai $13 \%$ dari penyakit secara keseluruhan dan diperkirakan akan berkembang menjadi $25 \%$ di tahun 2030 . Gangguan jiwa menyebabkan hilangnya produktifitas, dan mudah kambuh sehingga meningkatkan biaya perawatan.

Dampak gangguan jiwa menyebabkan keluarga kehilangan banyak waktu untuk merawat, mengalami beban emosional, dan sosial akibat stigma dari masyarakat (Hogan, 2008). Asmedi (2012), mengungkapkan di Indonesia gangguan jiwa menimbulkan kerugian ekonomi mencapai Rp 20 triliun, akibat hilangnya produktivitas, beban ekonomi dan biaya perawatan kesehatan yang harus ditanggung keluarga dan negara. Klien gangguan jiwa tidak hanya membutuhkan dukungan ekonomi saja tetapi juga memerlukan sistem dukungan sosial yang mencakup dukungan emosional, informasional, instrumental dan penilaian/penghargaan untuk menjalani program pemulihan (recovery) dan menghadapi stigma di masyarakat.

Skizofrenia adalah bentuk gangguan jiwa yang sering dijumpai dan multifaktorial, perkembangannya dipengaruhi oleh faktor genetik dan lingkungan serta ditandai dengan gejala positif, negatif dan defisit kognitif (Jones et al, 2011). Peristiwa yang penuh stres, akan mengaktifkan aksis hipotalamushipofisis-adrenal dan merangsang pelepasan berbagai neurotransmitter otak, terutama dopamine dan norepinefrine, kejadian ini juga dianggap sebagai faktor 
kunci terjadinya skizofrenia (Bobo et al, 2008).

Gejala positif meliputi waham, halusinasi, gaduh gelisah, perilaku aneh, sikap bermusuhan dan gangguan berpikir formal. Gejala negatif meliputi sulit memulai pembicaraan, afek tumpul atau datar, kurangnya motivasi dan atensi, pasif, apatis dan penarikan diri secara sosial dan rasa tidak nyaman (Videbeck, 2008). Gejala defisit kognitif meliputi: gangguan dalam attention, learning and memory, dan gangguan dalam execution function, kerusakan kognitif ini sering diperburuk dengan kondisi insight yang buruk (Stuart, 2013).

Klien skizofrenia mengalami gejala positif, negatif dan defisit kognitif yang mempengaruhi pelaksanaan kegiatan harian dan penurunan fungsi sosial yang bermakna.

Skizofrenia membawa dampak bagi kehidupan individu, keluarga menghambat pelaksanaan pekerjaan, mengganggu masyarakat, dan merugikan negara. Adanya individu dengan gangguan jiwa (skizofrenia) meningkatkan cost dan beban ekonomi tidak hanya bagi keluarganya tetapi juga negara. Individu dengan skizofrenia tidak hanya kehilangan kesempatan untuk bekerja tetapi yang sudah bekerja juga dapat kehilangan pekerjaan.

Mosanya et al (2014) mengungkapkan kondisi klien yang tidak produktif, dan tidak berpenghasilan menimbulkan stigma di masyarakat bahkan keluarga dan mempengaruhi stigma diri sehingga klien cenderung mengalami harga diri rendah. Pendidikan rendah, tidak bekerja dan tidak ada penghasilan memberikan konstribusi menurunnya harga diri dan mempengaruhi kualitas hidup klien (Mosanya et al, 2014).

Berdasarkan latar belakang di atas maka penulis tertarik untuk menganalisa faktor-faktor penyebab gangguan jiwa di Ruang Kresna (Ruang Akut) Wanita Rumah Sakit Dr. H. Marzoeki Mahdi Bogor.

\section{METODE PENELITIAN}

Desain dalam penelitian ini adalah deskriptif kuantitatif yang melihat gambaran faktor-faktor penyebab gangguan jiwa. Populasi penelitian ini adalah semua klien yang dirawat di Ruang Akut RS Jiwa Dr. Marzoeki Mahdi Bogor. Sampel dalam penelitian ini adalah sebagian klien yang dirawat di Ruang Akut RS Jiwa Marzoeki Mahdi Bogor dengan menggunakan metode purposive sampling dengan dibatasi waktu yaitu 9 minggu. Jumlah sample pada penelitian ini adalah 46 responden.

\section{HASIL PENELITIAN}

Hasil penelitian ini akan dijabarkan tentang karakteristik responden dan faktor-faktor penyebab gangguan jiwa.

Tabel 1 Karakteristik Klien di Ruang Kresna Wanita RSMM Bogor $(\mathrm{n}=46)$

\begin{tabular}{|c|c|c|c|}
\hline No & Karakteristik Klien & Jumlah & $\begin{array}{c}\text { Prosentase } \\
(\%)\end{array}$ \\
\hline \multirow[t]{2}{*}{1.} & Jenis kelamin: & & \\
\hline & Perempuan & 46 & 100 \\
\hline \multirow[t]{5}{*}{2.} & Usia: & & \\
\hline & a. Remaja (12-18 tahun) & 3 & 6,5 \\
\hline & $\begin{array}{l}\text { b. Dewasa muda (18-25 } \\
\text { tahun) }\end{array}$ & 8 & 17,4 \\
\hline & c. Dewasa (26-60 tahun) & 32 & 69,6 \\
\hline & $\begin{array}{l}\text { d. Lansia (lebih dari } 60 \\
\text { tahun) }\end{array}$ & 3 & 6,5 \\
\hline \multirow[t]{6}{*}{3.} & Pendidikan: & & \\
\hline & a. Tidak sekolah & 4 & 8,7 \\
\hline & b. SD & 12 & 26,1 \\
\hline & c. SMP & 8 & 17,4 \\
\hline & d. SMA & 19 & 41,3 \\
\hline & e. PT & 3 & 6,5 \\
\hline \multirow[t]{3}{*}{4.} & Pekerjaan: & & \\
\hline & a. Tidak bekerja & 41 & 89,1 \\
\hline & b. Bekerja & 5 & 10,9 \\
\hline \multirow[t]{4}{*}{5.} & Status pernikahan: & & \\
\hline & a. Belum menikah & 16 & 34,8 \\
\hline & b. Menikah & 19 & 41,3 \\
\hline & c. Janda & 11 & 23,9 \\
\hline \multirow[t]{4}{*}{6.} & $\begin{array}{l}\text { Lama sakit (rata-rata: } 8 \\
\text { tahun } 6 \text { bulan): }\end{array}$ & & \\
\hline & a. Kurang dari 1 tahun & 12 & 26,1 \\
\hline & b. $\quad 1-5$ tahun & 12 & 26,1 \\
\hline & c. Lebih dari 5 tahun & 22 & 47,8 \\
\hline
\end{tabular}


Faktor penyebab gangguan jiwa dibagi menjadi 2, yaitu faktor predisposisi dan presipitasi yang meliputi biologis, psikologis dan sosial. Berikut ini merupakan gambaran faktor-faktor penyebab gangguan jiwa yang terjadi pada responden:

Tabel 2 Faktor Predisposisi $(n=46)$

\begin{tabular}{|c|c|c|c|}
\hline No & Bentuk Perilaku & Jumlah & $\begin{array}{c}\text { Prosentase } \\
(\%)\end{array}$ \\
\hline \multirow[t]{5}{*}{1.} & Biologis: & & \\
\hline & 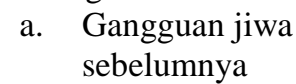 & 32 & 56,2 \\
\hline & b. Keturunan & 13 & 22,8 \\
\hline & c. Trauma kepala & 6 & 10.5 \\
\hline & $\begin{array}{l}\text { d. } \begin{array}{l}\text { Penyakit } \\
\text { kronis }\end{array}\end{array}$ & 6 & 10.5 \\
\hline \multirow[t]{7}{*}{2.} & Psikologis: & & \\
\hline & $\begin{array}{ll}\text { a. } & \text { Tipe } \\
\text { kepribadian }\end{array}$ & 39 & 29,4 \\
\hline & $\begin{array}{l}\text { b. Pengalaman } \\
\text { tidak }\end{array}$ & 27 & 22,7 \\
\hline & menyenangkan & 11 & 9,3 \\
\hline & c. Keinginan & 5 & 4,2 \\
\hline & $\begin{array}{l}\text { tidak terpenuhi } \\
\text { d. Konsep diri } \\
\text { negatif }\end{array}$ & 4 & 3,4 \\
\hline & e. Pola asuh & & \\
\hline \multirow[t]{8}{*}{3.} & Sosial: & & \\
\hline & a. Tidak bekerja & 41 & 23,8 \\
\hline & $\begin{array}{l}\text { b. Tidak ikut } \\
\text { kegiatan sosial }\end{array}$ & 30 & 17,4 \\
\hline & $\begin{array}{l}\text { Tidak } \\
\text { mempunyai } \\
\text { teman dekat }\end{array}$ & 28 & 16,3 \\
\hline & $\begin{array}{ll}\text { d. } & \text { Konflik } \\
\text { dengan } \\
\text { keluarga/teman }\end{array}$ & 23 & 13,4 \\
\hline & $\begin{array}{l}\text { e. Penghasilan } \\
\text { kurang }\end{array}$ & 19 & 11,1 \\
\hline & $\begin{array}{ll}\text { f. } & \text { Tidak } \\
& \text { sekolah/putus } \\
& \text { sekolah }\end{array}$ & 18 & 10,5 \\
\hline & $\begin{array}{ll}\text { g. } & \text { Kehilangan } \\
\text { orang berarti }\end{array}$ & 13 & 7,6 \\
\hline
\end{tabular}

Tabel di atas menunjukkan bahwa pada faktor predisposisi, penyebab pada aspek biologis terbanyak adalah klien pernah mengalami gangguan jiwa sebelumnya yaitu sebanyak 32 responden $(36,2 \%)$, penyebab pada aspek psikologis terbanyak adalah tipe kepribadian yaitu sebanyak 39 responden $(29,4 \%)$ dan penyebab pada aspek sosial terbanyak adalah klien tidak bekerja yaitu sebanyak 41 responden $(23,8 \%)$.

Tabel 3 Faktor Presipitasi $(\mathrm{n}=46)$

\begin{tabular}{|c|c|c|c|}
\hline No & Bentuk Perilaku & Jumlah & $\begin{array}{l}\text { Prosentase } \\
\quad(\%)\end{array}$ \\
\hline \multirow[t]{4}{*}{1.} & Biologis: & & \\
\hline & a. Putus obat & 32 & 69,6 \\
\hline & b. Penyakit fisik & 7 & 15,2 \\
\hline & c. Trauma kepala & 1 & 2,2 \\
\hline \multirow[t]{3}{*}{2.} & Psikologis: & & \\
\hline & $\begin{array}{l}\text { a. Pengalaman } \\
\text { tidak } \\
\text { menyenangkan }\end{array}$ & 21 & 45,8 \\
\hline & $\begin{array}{l}\text { b. Keinginan tidak } \\
\text { terpenuhi }\end{array}$ & 4 & 8,7 \\
\hline \multirow[t]{6}{*}{3.} & Sosial: & & \\
\hline & $\begin{array}{l}\text { a. Konflik dengan } \\
\text { keluarga/teman }\end{array}$ & 17 & 37 \\
\hline & $\begin{array}{l}\text { b. Penghasilan } \\
\text { kurang }\end{array}$ & 4 & 8,8 \\
\hline & c. Tidak bekerja & 2 & 4,4 \\
\hline & $\begin{array}{ll}\text { d. } & \text { Tidak } \\
& \text { sekolah/putus } \\
& \text { sekolah }\end{array}$ & 2 & 4,4 \\
\hline & $\begin{array}{ll}\text { e. } & \text { Kehilangan } \\
\text { orang berarti }\end{array}$ & 2 & 4,4 \\
\hline
\end{tabular}

Tabel di atas menunjukkan bahwa pada faktor presipitasi, penyebab pada aspek biologis terbanyak adalah putus obat yaitu sebanyak 32 responden $(69,6 \%)$, penyebab pada aspek psikologis terbanyak adalah pengalaman tidak menyenangkan yaitu sebanyak 21 responden $(45,8 \%)$ dan penyebab pada aspek sosial terbanyak adalah konflik dengan keluarga atau teman yaitu sebanyak 17 responden (37\%).

\section{PEMBAHASAN}

Gangguan jiwa dapat terjadi pada siapa saja, baik yang berusia muda, dewasa maupun lansia. Gangguan jiwa juga dapat terjadi pada orang yang tinggal di perkotaan maupun di pedesaan.

Hasil penelitian menunjukkan bahwa usia terbanyak yang mengalami gangguan jiwa adalah usia dewasa. Usia dewasa merupakan usia produktif dimana mereka harus mampu secara mandiri menghidupi dirinya sendiri. Usia ini juga usia dimana seseorang telah berkeluarga, sehingga masalah yang dihadapi juga semakin 
banyak, bukan hanya masalahnya sendiri namun harus memikirkan masalah anggota keluarganya. Hal ini memungkinkan orang dewasa mempunyai masalah yang lebih kompleks dan berisiko mengalami gangguan jiwa.

Hasil penelitian menunjukkan bahwa yang mengalami gangguan jiwa adalah yang tidak bekerja. Tidak bekerja bisa membuat orang kehilangan kesempatan untuk mempunyai penghasilan. Tidak bekerja juga bisa membuat orang kehilangan kesempatan untuk menunjukkan aktualisasi dirinya. Hal ini yang dapat membuat orang tidak melakukan suatu kegiatan, sehingga akan sangat memungkinkan orang mengalami harga diri rendah yang akan berdampak pada gangguan jiwa.

Hasil penelitian menunjukkan bahwa faktor predisposisi biologis terbanyak adalah adanya gangguan jiwa sebelumnya. Ketika seorang klien sudah pernah mengalami gangguan jiwa sebelumnya, walau klien telah dinyatakan sembuh dan dapat kembali ke masyarakat, namun stigma negatif yang ada di masyarakat telah membuat klien ditolak atau tidak diperlakukan baik di masyarakat.

Tipe kepribadian tertutup juga merupakan penyebab terbanyak orang mengalami gangguan jiwa. Orang dengan tipe kepribadian tertutup akan cenderung menyimpan segala permasalah sendiri, sehingga masalah akan semakin menumpuk. Hal ini yang akan membuat klien bukannya menyelesaikan permasalahannya, namun akan bingung dengan permasalahannya dan dapat membuat klien depresi.

Putus obat juga merupakan salah satu faktor presipitasi gangguan jiwa. Klien yang mengalami gangguan jiwa, kebanyakan harus minum obat seumur hidupnya. Hal ini yang menyebabkan klien merasa bosan minum obat dan akan menghentikan minum obat. Selain karena merasa bosan, klien yang mempunyai pengetahuan kurang juga akan menghentikan minum obat karena merasa sudah sembuh atau gejala tidak muncul. Hal ini yang akan memicu kekambuhan gangguan jiwa atau munculnya gangguan jiwa kembali.

Pengalaman tidak menyenangkan yang dialami klien misalnya adanya aniaya seksual, aniaya fisik, dikucilkan oleh masyarakat atau kejadian lain akan memicu klien mengalami gangguan jiwa. Klien yang mempunyai mekanisme koping maladaptif akan membuat klien mudah mengalami gangguan jiwa.

Selain itu konflik dengan teman atau keluarga misalnya karena harta warisan juga dapat membuat klien mengalami gangguan jiwa. Konflik yang tidak terselesaikan dengan teman atau keluarga akan memicu klien mengalami stresor yang berlebihan. Jika klien yang mengalami stresor berlebihan namun mekanisme kopingnya buruk, maka akan membuat klien mengalami gangguan jiwa.

\section{KESIMPULAN}

Kesehatan jiwa merupakan bagian yang tidak terpisahkan dari kesehatan secara umum serta merupakan dasar bagi pertumbuhan dan perkembangan manusia. penyebab gangguan jiwa terdiri dari faktor penyebab predisposisi dan presipitasi. Faktor ini ditinjau dari aspek biologis, psikologis dan sosial.

Faktor predisposisi terbanyak pada aspek biologis adalah klien pernah mengalami gangguan jiwa sebelumnya, pada aspek psikologis adalah tipe kepribadian dan penyebab pada aspek sosial adalah klien tidak bekerja, sedangkan faktor presipitasi, penyebab pada aspek biologis terbanyak adalah putus obat, penyebab pada aspek psikologis terbanyak adalah pengalaman tidak menyenangkan dan penyebab pada aspek sosial terbanyak adalah konflik dengan keluarga atau teman.

\section{SARAN}

Semua orang berisiko terjadinya gangguan jiwa. Oleh karena itu perlu adanya kerjasama dari semua pihak untuk 
mengurangi atau mencegah angka kekambuhan atau terjadinya gangguan jiwa. Saran bagi tenaga kesehatan adalah tenaga kesehatan dapat saling bekerjasama untuk mengurangi faktor penyebab gangguan jiwa dengan melakukan tindakan pencegahan kekambuhan atau tindakan pencegahan terjadinya gangguan jiwa yang berbasis masyarakat. Selain itu tenaga kesehatan juga dapat melakukan tindakan kepada keluarga karena keluarga merupakan orang terdekat yang akan merawat klien saat di rumah. Selain keluarga, masyarakat sekitar juga perlu diberikan pengetahuan tentang cara merawat klien yang sudah kembali ke rumah. Kerjasama dengan pihak Puskesmas dan atau kader kesehatan (terutama kader kesehatan jiwa) juga sangat diperlukan untuk keberlangsungan hidup klien gangguan jiwa yang telah kembali ke masyarakat.

\section{DAFTAR PUSTAKA}

Asmedi, ed, (2012). Gangguan Jiwa di Indonesia Masih Terabaikan, Kompas 11 Februari 2012.

Bobo, W.V., Rapoport, J.L., AbiDargham, A., Fatemi, H., dan Meltzer, H.Y. (2008). The Neurology of Schizophremia. Chapter 19. Psychiatry. Third Edition. John Welly \& Sons. Ltd, New York

Hogan, M.F. (2008). Assessing the Economic Costs of Serious Mental Illness. American Journal Psychiatry. 165:6, June 2008

Jones, J.S., Fitzpatrick, J.J., dan Rogers, V.L. (2012). Psychiatric mental health nursing an interpersonal approach. New York: Springer Publishing Company
Kementerian Kesehatan. (2009). UU No 36 Tahun 2009 tentang Kesehatan. Jakarta

Mosanya, T.J., Adelufosi, A.O., Adebowale, O.T., Ogunwalie, A., Adebayo, O.K. (2014). Self-stigma, quality of life and schizophrenia: An outpatient clinic survey in Nigeria. International Journal of Social Psychiatry. 2014, Vol. 60(4) 377386.

DOI:

$10.1177 / 0020764013491738$

Stuart, G.W. (2013). Principles and Practice of Psychiatric Nursing. $10^{\text {th }}$ Ed. Canada: Evolve.

Videback, S.L. (2011). PsychiatricMental Health Nursing. $4^{\text {th }}$ Ed. China: Wolters Kluwer. 